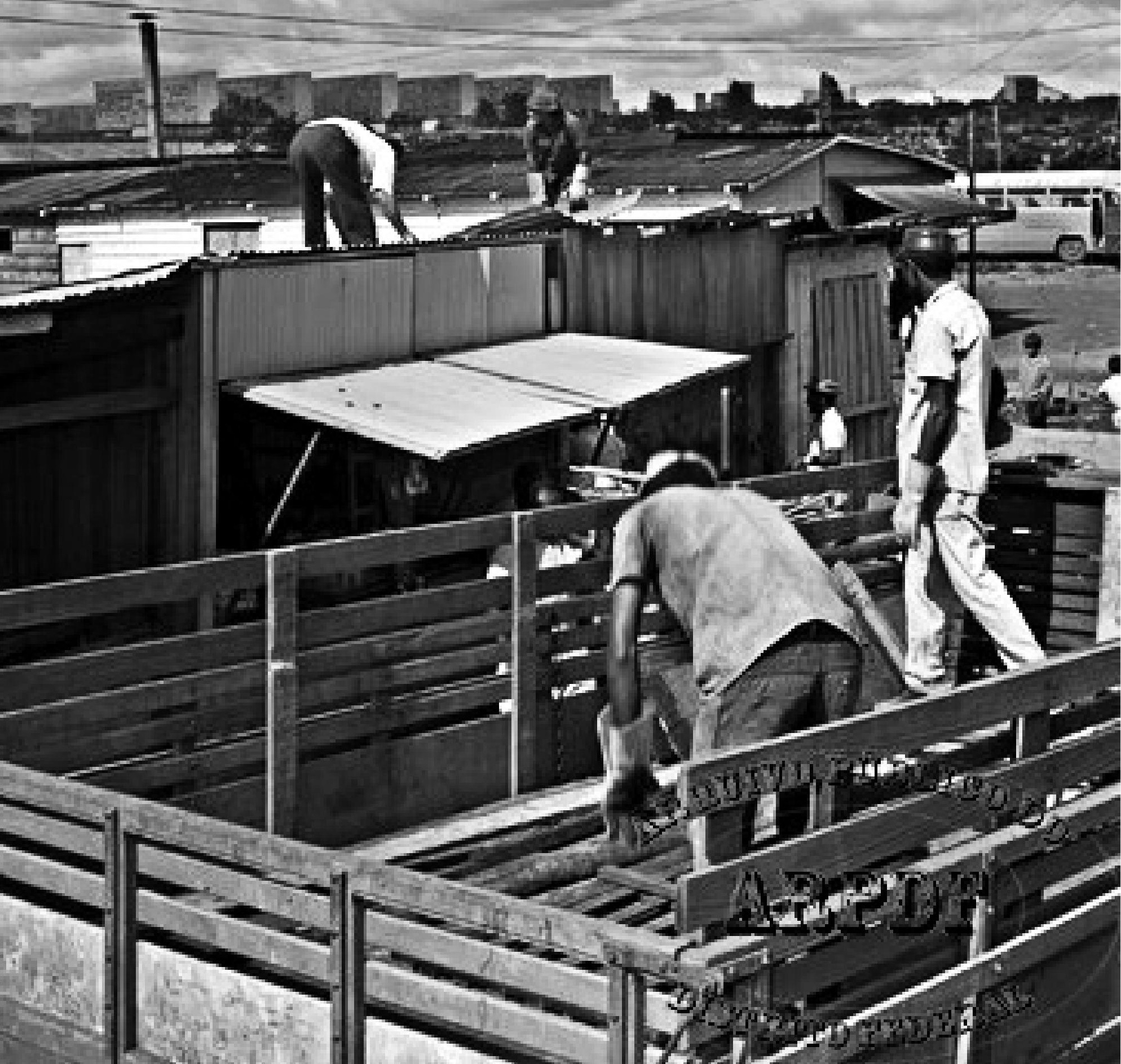




\title{
RESENHA
}

\section{O mundo moderno em Hegel, Marx e Nietszche à luz de Henri Lefebvre: crítica espacial}

The modern world in Hegel, Marx and Nietzsche in the light of Henri Lefebvre: space critical

\author{
Everaldo Batista da Costa ${ }^{1}$ \\ Luana Nunes Martins de Lima² \\ Rafael Fabrício de Oliveira ${ }^{3}$ \\ Rúbia de Paula Rúbio ${ }^{4}$ \\ Wallace Rodrigues Pantoja ${ }^{5}$
}

1 Professor doutor do Departamento de Geografia e do Centro de Excelência em Turismo da UnB. Coordenador do Grupo de Pesquisa CNPq Cidades e Patrimonialização (GECIPA). Contato: everaldocosta@unb.br

2 Professora Assistente do Depto. de Geografia da UEG, Doutoranda em Geografia pelo PPGG-UnB. Integrante do Grupo de Pesquisa CNPq Cidades e Patrimonialização (GECIPA). Contato: luanunes_7@hotmail.com

3 Professor Assistente do Instituto Federal de São Paulo. Doutorando em Geografia pelo PPGG-UnB. Integrante do Grupo de Pesquisa CNPq Cidades e Patrimonialização (GECIPA). Contato: rafabricio@gmail.com

4 Mestre em Geografia pelo PPGG-UnB. Integrante do Grupo de Pesquisa CNPq Cidades e Patrimonialização (GECIPA). Contato: georubiarubio@gmail.com

5 Professor de Geografia e Estudos Amazônicos da SEDUC - Pará. Doutorando em Geografia pelo PPGG-UnB. Integrante do Grupo de Pesquisa CNPq Cidades e Patrimonialização (GECIPA). Contato: demithri@gmail.com 


\section{Nota aos leitores:}

Esta resenha da obra Hegel, Marx, Nietzsche o el reino de las sombras (do filósofo francês Henri Lefebvre) aproxima-se, em verdade, de um ensaio, pelo escopo que tomou, para além de uma sintética resenha. Tem-se por objetivo debater e sustentar a complexidade e a continuidade do mundo moderno, que se mantém pelas sombras de duras e paradoxais contradições do passado, via constituição do Estado, o discurso do social e da Sociedade e o ideal civilizacional ou de Civilização. Dimensões modernas que são avaliadas a partir de Hegel, Marx e Nietzsche, autores que dão aporte à ideia de uma geografia do mundo de existências, na qual o novo e a novidade (no viés das técnicas e das ideias) nunca abandonam totalmente o passado, ou seja, não há ruptura completa com a história, sempre renovada pelo espaço enquanto reflexo da interação permanente sociedade-natureza. Aparecem como temários: a concreticidade de práticas radicais revolucionárias entendidas no bojo da História (Marx), a subjetividade inerente ao corpo e às artes, responsáveis por resguardarem a ideia de uma nova Civilização (Nietzsche), e a vitória de um edifício estatal que a tudo e a todos controla (Hegel). Acredita-se na importância deste debate para o pensamento do mundo do presente, no viés dos questionamentos sistematizados favorecedores do repensar criticamente o espaço.

\section{PRÊAMBULO}

Uma vasta bibliografia atual, no campo das ciências humanas e da filosofia, sugere-nos a era do "pós", ou seja, a emergência de um momento cujo prefixo indica lógicas inteiramente novas: "pós-capitalismo", "pós-fordismo", "pós-industrial”, "pós-urbano", "pós-moderno" etc. Essa teoria tenta representar as mudanças frequentes do real, que no seio do capitalismo, em sua sequência evolutiva, se faz mais por reestruturações parciais e seletivas e menos por grandes reviravoltas, segundo Edward Soja. Quais dados mais precisos asseguram o absoluto fim do mundo moderno, para acreditar em algo totalmente novo categorizado como mundo pós-moderno? Nesse aspecto e a concordar com Soja (1993), não há justificativa para uma corrida ingênua e simplista ao "pós", que insista no derradeiro fim de uma era, como se o passado pudesse ser descascado e jogado fora.

Voltar à filosofia e aos clássicos, nesse sentido, possibilita justificar este ensaio, que objetiva tratar a ideia de que a história da sociedade é a própria geografia de existências em movimento, expressa em práticas espaciais retrato da interação permanente sociedade-natureza. Essa geografia do mundo de existências perpetua-se em choques e contradições sociais, onde o novo e a novidade (no viés das técnicas 
e das ideias) nunca abandonam (completamente) o passado, o que permite advogar pela não ruptura com o mundo moderno.

Logo, à luz do filósofo Henri Lefebvre, firme defensor do espaço na teoria social crítica, serão avaliadas três ideologias6 sobre as práticas sociais e políticas do mundo moderno, através de Hegel, Marx e Nietzsche. O pensamento hegeliano se concentra no conceito de Estado; a reflexão marxista foca no social e na sociedade; o ideário nietzschiano volta-se à civilização e seus valores. Os três autores suscitam o debate, ao seu modo, sobre as relações com o real, com a prática, para analisar a modernidade; prática esta avaliada por Henri Lefebvre em seu livro Hegel, Marx, Nietzsche o el reino de las sombras.7

Metodologicamente, para o alcance do objetivo do ensaio, fundamenta-se, notoriamente, na citada obra de Henri Lefebvre, bem como em trabalhos originais de Hegel, Marx e Nietzsche. Para a transposição da ideia, respectivamente, de Estado, Sociedade e Civilização, a partir destes autores, para a Geografia, buscam-se fundamentos nessa disciplina, bem como na História e na Sociologia, para caracterizar um ensaio.

Antes de passar à discussão introdutória do mundo moderno, a partir de Hegel, Marx e Nietzsche, cabe breve alusão ao título da obra de Lefebvre, o qual invoca os três autores e remete a um reino das sombras. O propósito desse chamado, em Hegel, está na própria composição do Sombrio Edifício do Estado. No caso de Marx, ao tomar como ponto de partida não o real, como o fez Hegel, mas o possível, penetrou o real com a ideia de sua transformação; porém, em Marx, a sombra se realiza quando as superestruturas estatais se desmoronam, como o queria, mas se reconstruíram, o que levou à decepção pela sombra de uma proposta revolucionária. Já Nietzsche, pretendeu deixar pistas para a metamorfose do real, buscando-o junto ao mais próximo, o corpo, detentor da razão; vislumbrou a morte do mundo moderno, com a transmutação de seus valores, até sua autodestruição; esboçou o demasiado humano para julgar o fim de uma consciência e de uma cultura, sempre acompanhado por sua própria sombra.

Em síntese, o ensaio vale-se de argumentos filosóficos e outros para provocar o

6 A noção de ideologia aqui empregada dialoga com a concepção do filósofo francês Gérard Fourez, para quem o discurso ideológico é uma representação adequada do mundo, mais com um caráter de legitimação do que unicamente descritivo. Henri Lefebvre, cuja obra orienta este ensaio, também reconhece os discursos dos três filósofos como ideológicos, e mais, expressam ideologias críticas das ideologias modernas ou suas expressões por meio do comunismo, do anticomunismo, do fascismo, do saber, do conhecimento etc.

7 O Grupo de Pesquisa Cidades e Patrimonialização, sediado no Departamento de Geografia da Universidade de Brasília, debate, anualmente, obras referenciais de métodos filosóficos emprestados à Geografia (voltadas à dialética, à fenomenologia e ao existencialismo). Por mais de um ano, o grupo se dedicou à citada obra de Henri Lefebvre. 
debate geográfico da complexidade terrível do mundo moderno que está aí e não cessou, mantém-se pelas sombras de duras e paradoxais contradições do passado, via constituição do Estado, o discurso do social e da Sociedade e o ideal civilizacional ou de Civilização. Seguem as possíveis contribuições desses filósofos ao debate geográfico da formatação de existências espaciais históricas no mundo moderno.

\section{O ESTADO, A AÇÃO POLÍTICA E O TERRITÓRIO EM HEGEL}

No Dossiê Hegel, Henri Lefebvre indica a essência do pensamento do filósofo no contexto de uma teoria política do Estado. Teoria esta pautada na racionalização de um Estado autorregulador e autogestor, que concentra e interliga saber e poder. Lefebvre explica que a teoria hegeliana baseia-se na formação do Estado-nação francês, a partir do século XVII. Ao correlacionar burguesia, saber, Estado-nação, a Revolução Francesa faz emergir novas contradições no cerne do indivíduo, do cidadão, do direito individual, dos conflitos do próprio Estado; o conhecimento passa a profano, racional e laico (logo, poder do Estado). Conforme o próprio Hegel ([1820] 1997, p. 225), "é o Estado a realidade em ato da liberdade concreta".

Henri Lefebvre esclarece que Hegel não discute apenas a filosofia, a ciência e sua história, antes disso, apresenta um discurso de alto grau, estratégico e definidor de ação política, de uma política absoluta destinada a absolutos políticos, que se mantém com o saber. Saber este que é o próprio Estado (saber puro e absoluto). Coincidem-se Saber e Estado, ou seja, o primeiro fundamenta e se subordina, simultaneamente, ao segundo. A teoria hegeliana do "edifício perfeito" do Estado, então, se faz a partir da relação estabelecida entre poder, saber e razão, a tríade de seu pensamento. Estado enquanto Ideia, unidade suprema, verdade, a própria realidade que se absolutiza por meio da razão. A tríade poder, saber e razão é o Estado hegeliano, que detém a realidade e está além da totalidade filosófica-histórica, das Ideologias. Estado que é criado a partir dele mesmo e para ele mesmo. O poder (como o saber) subordinado e inerente ao Estado hegeliano reúne na ordem política o trabalho, a família e os ofícios, os quais pareciam espontâneos. Nesse sentido, a violência coaduna-se à eficácia organizativa (expressas em leis coercitivas e ordenativas), fazendo-se legítima e justificada porque participa da vida política do Estado (conduzem à razão). Razão que, em Hegel, condiz com uma "fortuna universal" que permite, simultaneamente, a satisfação geral das necessidades, a mecanização do trabalho (da produção) e a autorregulação do conjunto social (ideia de equilíbrio e segurança a partir da ação do Estado); é um automatismo perfeito do conjunto no seio da abstração, em um edifício coerente horizontalmente (os elementos comple- 
mentares) e verticalmente (da base, a produção, acima, o chefe político) (Lefebvre, [1976] 2010). Em Hegel, o Estado aparece como produtor do indivíduo; é sabedor de si e de sua potência, de maneira a pouco importar o real destino deste indivíduo no seio do trabalho.

O Estado é a realidade em ato da Ideia moral objetiva, o espírito como vontade substancial revelada, clara para si mesma, que se conhece e se pensa, e realiza o que sabe e porque sabe. No costume tem o Estado a sua existência imediata; na consciência de si, no saber e na atividade do indivíduo, tem a sua existência mediata, enquanto o indivíduo obtém a sua liberdade substancial ligando-se ao Estado como à sua essência, como ao fim e ao produto da sua atividade. (Hegel, [1820] 1997, p. 216)

Hegel desconsidera que a divisão do trabalho mutila o indivíduo, além de esconder a essência do processo de produção e o conhecimento do conjunto sociopolítico; passa ao largo sobre a destinação dos territórios dominados política ou estrategicamente. A máquina política - o conjunto automático - se converte em realidade com a substituição do trabalho por máquinas; a máquina política gira sem fim sobre si mesma, com todas suas rodas e engrenagens; nisso, o Estado se autogera e regula, permanece estável no consumo dos objetos e no esfacelamento dos sujeitos (Lefebvre, [1976] 2010).

O Estado hegeliano é constitucional e fundado na consciência e cultura da classe média, explica Henri Lefebvre; nem camponeses nem trabalhadores, classes trabaIhadoras produtivas são pilares do Estado. Os funcionários do Estado, por meio de concursos ou coação, estão no Estado (sua base social e substância). Em Hegel, essas classes sociais estão em luta e contradições: classe natural (arraigada no solo, camponeses); classe ativa (artesão, trabalhadores habilidosos); classe pensante (maneja o conjunto social dentro do marco Estatal). São três classes que constituem a sociedade civil e o conflito dessas classes faz emergir a classe política, diretamente vinculada ao Estado como seu aparato. Essa classe política, uma classe de benefícios, reconhece as contradições sociais, o que favorece a manutenção do próprio Estado como totalidade coerente, dadas as estratégias criadas. Essa classe política representa a "vida do todo", a produção constante da sociedade, do Estado, da constituição, do ato político mesmo que consiste em governar (Lefebvre, [1976] 2010).

Em resumo, essas três classes convivem de forma conflituosa ao ponto de nutrir o surgimento da classe política diretamente ligada ao Estado, "substância da vida do todo" e por isso não é subordinada à divisão do trabalho; a força desses conflitos, bem como o absoluto que rege o Estado fundamenta-se na ideia de Religião (e não seria a Igreja, com a doutrina religiosa e detentora do conhecimento fundamental, 
pilar do Estado moderno? Não seria a instituição a balizar o controle socioterritorial, em países de continentes colonizados da América Latina, África e Ásia, por meio da difusão de consciências ou saberes?).

Só com os conceitos de Religião e de Estado é que se pode obter a determinação essencial das suas relações. O conteúdo da religião é a verdade absoluta e, portanto, ao seu domínio pertence o grau mais elevado do sentimento. Como intuição, como sentimento, princípio e causa infinita de que tudo depende, a que tudo se refere, a religião exige que tudo se conceba do seu ponto de vista e nela tenha a confirmação, a justificação e a certeza. O Estado e as leis, bem como os deveres, nesta dependência, obtêm a soberana garantia e a mais elevada obrigação para a consciência. Com efeito, o Estado, as leis e os deveres são, em realidade, algo de definido que se liga a uma esfera mais elevada como ao seu princípio. Assim se explica que a religião contenha aquele ponto que, na alteração universal e na evanescência dos fins, dos interesses e das propriedades reais, garante a consciência do imutável, da liberdade e da soberana satisfação [...] O Estado é a vontade divina como espírito presente ou atual que se desenvolve na formação e organização de um mundo [...] A Religião é a relação com o absoluto na forma do sentimento, da imaginação e da crença, e no centro dela, que contém tudo o que é, tudo o que existe torna-se um acidente que se evanesce [...] É o conhecimento filosófico que sabe que o Estado e a Igreja não se opõem quanto ao conteúdo da verdade e da razão, mas apenas quanto à forma. Quando, portanto, a Igreja transita para o ensino (houve e há igrejas que se limitam ao culto, outras em que o culto é o essencial e em que o ensino e a cultura da consciência é acessório) e o seu ensino se ocupa dos princípios objetivos e da reflexão sobre a moral objetiva e a razão, a Igreja interfere no que é domínio do Estado. Ora, diante da crença e da autoridade que ela invoca e apresenta a propósito da moral, do direito, das leis e das instituições, diante da sua opinião subjetiva, é o Estado que representa o saber; do seu princípio provém, com efeito, que o conteúdo não se encerra na forma do sentimento e da crença, mas se liga ao pensamento definido. (Hegel, [1820] 1997, p. 233-34, 240-41)

O espírito absoluto do Estado, pautado, então, na Religião, também se conserva pela importância da classe política que, para Hegel, está em sua capacidade de manter a unidade do Estado. Decorre daí que, ao invés da resolução dos conflitos, se dá a diluição destes; busca-se reestabelecer definitivamente a coesão por meio do autoritarismo (coerção), que para Hegel é justificado em nome da ordem política. A classe política "assegura o funcionamento da sociedade [...] conhece o conjunto social e, portanto, o faz funcionar [...] A classe política, o saber, sustentam o Estado e o fazem resistir" (Lefebvre, [1976] 2010, p. 86).

O debate hegeliano do Estado é herança dos acontecimentos chaves ou princípios 
da subjetividade moderna, que são a Reforma, a llustração e a Revolução Francesa, a denotar uma visão eurocêntrica da modernidade via fenômenos intraeuropeus, de forma que parece não se precisar mais que a Europa para se explicar o processo da modernidade (Dussel, 2000). Do ponto de vista geográfico político, verifica-se a centralidade da Europa latina na ideia de história mundial, que é a determinação fundamental da modernidade inaugurada juntamente com o mercantilismo e o bulionismo mundiais; entenda-se que nunca houve, empiricamente, história mundial, até fins do século XV.

La Modernidad, como nuevo 'paradigma' de vida cotidiana, de comprensión de la historia, de la ciencia, de la religión, surge al final del siglo XV y con el dominio del Atlántico. El siglo XVII es ya fruto del siglo XVI; Holanda, Francia, Inglaterra, son ya desarrollo posterior en el horizonte abierto por Portugal y España. América Latina entra en la modernidad como la 'otra cara' dominada, explotada, encubierta (Dussel, 2000, p. 48).

Nesse viés geográfico político, deve-se reconhecer que a teoria hegeliana do Estado enaltece uma autoconsciência europeia em torno da modernidade. Ao mesmo tempo que parece negar, fundamenta a latência do contraste essencial da conformação colonial do mundo entre ocidental ou europeu (entendido como o moderno, o avançado) e os outros, o resto dos povos e culturas do planeta (Lander, 2000). Para Edgardo Lander, a conquista ibérica do continente americano é o momento fundante dos dois processos que articuladamente conformam a história posterior: a modernidade e a organização colonial do mundo - movimento que ainda está em voga, em novas roupagens. $O$ que se pretende defender é o cuidado na interpretação do debate do Estado hegeliano, para alcançar a essência que regeu (e ainda rege) o colonialismo mundial, que inicia não só a organização colonial do mundo, mas, junto a isso, a forja de todas as culturas, povos e territórios do planeta, passados e presentes, "uma grande narrativa universal" (Lander, 2000, p. 16). No ceio da ação política debatida por Hegel, no que tange a expansão territorial de nações, de forma eurocêntrica, reducionista e até simplista em que, por exemplo, o tráfico aparece como "elemento de cultura", o filósofo entende que:

[...] a sociedade civil é impelida para além dela mesma; é obrigada a procurar fora de si os consumidores e, portanto, os meios de subsistir, recorrendo a outros povos que the são inferiores nos recursos que ela possui em excesso, em geral na indústria. Assim como o princípio da vida da família tem por condição a terra e o solo, assim o elemento natural que exteriormente anima a indústria é o mar. A procura do ganho, na medida em que implica um risco, eleva-se acima do seu próprio fim e substitui o apego a terra e ao círculo limitado da vida civil, por prazeres e desejos particulares inerentes à fluidez, ao 
perigo e ao naufrágio possível. Estabelece, além disso, relações de tráfico entre os países mais afastados e através do mais vasto meio de ligação. $O$ tráfico promove uma atividade jurídica que produz 0 contrato; constitui, ao mesmo tempo, um poderoso instrumento de cultura e nele encontra o comércio a sua significação histórica [...] Para ver os meios de cultura que há no contato com o mar, apenas basta comparar a atitude das nações onde a indústria prosperou com a daquelas que se negaram à navegação, como os egípcios e os hindus, todos voltados para si mesmos e mergulhados nas mais horrorosas e desprezíveis superstições. Pelo contrário, todas as grandes nações, as que fazem um esforço sobre si mesmas, procuram o mar. Este alargamento das relações oferece também um instrumento de colonização, para a qual é impelida, numa forma sistemática ou esporádica, toda a sociedade civil completa. É a colonização que permite a uma parte da população regressar, num novo território, ao princípio familiar e de, ao mesmo tempo, obter novas aplicações para o seu trabalho (Hegel, [1820] 1997, p. 209-11).

A "leveza" presente no debate de Hegel, que negligencia o espaço e o território enquanto reflexos de um Estado absoluto, sugere que as instâncias políticas são capazes de conhecer (por deter o saber) e de resolver (graças ao poder coercitivo) todas as contradições de níveis subalternos relativos ao "edifício do Estado"; as contradições aparecem em Hegel como momentos passageiros de um todo coerente, onde vigora uma harmonia. Porém, como destaca Henri Lefebvre, escapa à Hegel o espaço, demasiado complexo, com demasiadas gentes, lugares e coisas; demasiadas relações difíceis de dominar entre os centros e as periferias. "Ao perder de vista o espaço, o Estado perde de vista as fissuras sociais" (Lefebvre, [1976] 2010, p. 120).

Henri Lefebvre elucida, portanto, para cada um dos três autores escolhidos, o porquê de trazê-los numa tríade que dispõe sobre o Reino das Sombras. No que concerne a Hegel, o Reino das Sombras é a sua construção política acerca do edifício do Estado Absoluto. Argumenta Lefebvre que há uma leitura em termos de "onipresença" e "onipotência" deste Estado, que é liberal e é autoritário, regido por um sistema lógico pautado na razão, que o totaliza como autogestor e autorregulador. "Descreveu inclusive o aborrecimento moral que dele resulta: a sombra sobre a terra do Sol da Ideia e o sombrio edifício do Estado" (Lefebvre, [1976] 2010, p. 64).

Em síntese, o Estado Moderno reproduz, incorpora e faz perpetuar, nos territórios, a trindade trabalho, ação e pensamento, por mais que Hegel negligencie a fragmentação dialética dos territórios potencializados no trabalho. Na classe média emergente - que tem uma ilusória importância política, pois é a camada mais elevada da classe média quem domina, a chamada classe política - o gigante demasiado humano é o Estado, afirma Henri Lefebvre. Hegel ilumina o Estado, todo o Estado 
atado às suas próprias presas; burocrático e da força bruta (suas duas vertentes potenciais), graças ao saber a ele subordinado.

Na geografia histórica do mundo moderno, com foco na constituição estatal, o "edifício social" nunca deixou de ser regido pelos aparatos que mantém esse Estado, que assegura e define a civilização através do saber, da religião e da cultura de uma parcela da classe média e da alta, tudo a arrasar ou a abstrair o vivido e o cotidiano, o que o caracteriza como hegeliano. Por outro lado, hoje, o Estado perde verve hegeliana, dada a repartição político-territorial do poder. Impossível falar em um poder unitário, face às múltiplas resistências de nações espalhadas pela Terra e à tentativa de constituição de poderes hegemônicos, além do poder triádico (executivo, legislativo e judiciário). Essas duas dimensões reforçam a ideia de permanências modernas absolutas no fazer social de um debatido Estado "pós-moderno", caracterizado por fissuras políticas e territoriais.

\section{A SOCIEDADE, O ESTADO E A REVOLUÇÃO EM MARX}

O pensamento de Marx tem uma relação dialética com o pensamento de Hegel. Isso equivale a dizer que ocorre uma relação de unidade e de conflitos entre as duas abordagens, que implica um lastro essencial, traduzido por importante legado de Hegel a Marx, o que significa ideias tomadas do primeiro pelo último: o papel do trabalho, a lógica da produção e a importância das classes sociais na apreensão dos fenômenos sociais. Todavia, Marx trata estas noções em uma base material, dinâmica e totalizante.

Conforme Lefebvre ([1976] 2010, p. 19), a história, acabada segundo Hegel, prossegue segundo Marx, ou seja, Marx tomou de Hegel o essencial de seu pensamento 'essencialista': importância do trabalho e da produção, autoprodução da espécie humana (do homem), racionalidade imanente na prática, na consciência e no saber, tanto como nas lutas políticas, quer dizer, no sentido da história. Nesse movimento do pensar (o qual segue o curso da vida concreta), a realidade prática precede a ideia, onde o meio e as relações têm papeis centrais no decurso social, ao operarem a história e a possibilidade do devir.

Marx atua na transferência da dialética idealista hegeliana para uma dialética materialista. Mais que uma ruptura filosófica (do idealismo ao materialismo) ou epistemológica (da ideologia à ciência), Marx promove um corte político, quando busca desmantelar a construção hegeliana de Estado e outros conceitos, os quais ganham, em Marx, status social e científico, como a alienação, pela razão da tríade exploração -opressão-humilhação, com o potencial dos conceitos de mais-valia, valor, de valor- 
-de-uso e de valor-de-troca. Se em Hegel o Estado é a estrutura da sociedade, em Marx, o Estado é, sobretudo, a Superestrutura construída historicamente, pelas relações sociais de produção, forças produtivas, políticos, homens do Estado (Lefebvre, [1976] 2010). Ganha originalidade, em Marx, a dialética hegeliana, na qual a racionalidade se revela inerente à pratica social e redunda na prática industrial, que transforma, junto com as relações sociais, o cotidiano. Para Marx, o Estado (burguês e instável) administra a sociedade conforme as estratégias da classe dominante (de saúde, educação, conhecimento, serviços sociais diversos). Mesmo no interior dessa classe, há o domínio que controla, inclusive, a classe econômica dominante, privando-a de sua hegemonia (o Estado surge de uma operação militar - fascismo, bonapartismo, etc), lembra Henri Lefebvre.

Conforme Marx, em Manuscritos econômicos, a materialidade do mundo, o imediatamente perceptível, é a expressão material e sensível da vida humana alienada. O grande movimento desta vida - a produção e o consumo - representa a manifestação sensível do movimento de toda a produção anterior, quer dizer, a realização ou realidade do homem em seu decurso histórico. A religião, a família, o Estado, o Direito, a moral, a ciência, a arte, etc., constituem apenas modos particulares da produção e submetem-se à sua lei geral.

Se a tríade hegeliana centra-se em necessidades, trabalhos e gozo, a tríade marxista constitui-se, autenticamente, na opressão, exploração e humilhação, ou ainda, ideologia, violência, saber, em uma terminologia atual, políticos, militares, tecnocratas, afirma Lefebvre. Por isso, as transformações do Estado moderno o "hegelianizaram", quando aparece dividido em dois polos: oficina de estudos ou banco de dados a serviço das organizações econômicas e das empresas; aparato opressor e repressor, policialesco e militar, que domina a sociedade civil e tende a escravizá-la para explorá-la por sua própria conta (Lefebvre, [1976] 2010). Nesse aspecto, por meio da burocracia, a classe econômica dominante exerce sua hegemonia e modela, inclusive, as necessidades, o saber, o espaço social. A sociedade é dominada ou controlada e não administrada ou atendida.

Nessa lógica, Marx indaga se o "dinheiro é o vínculo que me liga à vida humana, que liga a sociedade a mim, que me une à natureza e ao homem, não será ele o laço de todos os laços? Não poderá ele soltar e unir todos os vínculos? Não será ele, portanto, o meio universal de separação? Constitui o verdadeiro meio de separação e união, a força galvano-química da sociedade"; e prossegue:

Shakespeare enfatiza duas propriedades do dinheiro: 1) ele é a divindade visível, a transformação de todas as qualidades humanas e naturais no seu oposto, a universal confusão e inversão das coisas; 
estabelece a fraternidade entre o que é incompatível; 2) ele é a prostituta universal, a universal alcoviteira dos homens e dos povos. 0 poder de perversão e de inversão de todas as qualidades humanas e naturais, a capacidade de entre coisas incompatíveis estabelecer a fraternidade. A força divina do dinheiro reside no seu caráter como ser genérico alienado e auto-alienante do homem. Ele é o poder alienado da humanidade. (Marx [1844] 2003, p. 169).

A proposta marxiana é a de uma revolução a ser feita contra o Estado, potencializada e plenamente realizada no contexto de uma práxis integradora, capaz de exterminar os privilégios institucionais. Esta perspectiva subsidia uma profunda reflexão e consequente crítica à ideia hegeliana de um Estado harmonioso e racional, inspirado no contexto europeu bismarckiano e bonapartista, mas também crítica ao paradigma positivista. Henri Lefebvre lembra que, para Marx, a classe trabalhadora deveria atuar segundo suas análises teóricas, segundo as indicações do conhecimento, ao invés de proceder, por vezes, especulativamente (como os filósofos) e outras empiricamente (como os políticos profissionais), por isso poderiam ir mais longe que a burguesia. "Os filósofos se limitaram a interpretar o mundo de diferentes maneiras, o que importa é transformá-lo" (Marx [1848] 2003, p. 113). Porém, o marxismo tornou-se ideologia e o projeto de uma sociedade comunista, retórica. A crítica radical do Estado, para Marx, Engels, Lenin se transformou em doutrina do Estado, mais que metáfora, uma metamorfose; o pensamento de Marx, que elaborou o conceito de ideologia e quis eliminar toda ideologia, se converte em ideologia; seu próprio pensamento cai no reino das sombras (Lefebvre, [1976] 2010).

Nesse aspecto, pode-se entender a atualidade do debate marxiano e marxista para a Geografia. Enquanto ciência humana que busca desvendar ou lançar luz sobre as contradições socioespaciais advindas de interações com a natureza, a obra de Marx auxilia a entender a história social como a própria geografia de existências em conflitos expressos por práticas espaciais, que envolvem a metamorfose de ações, de objetos e de técnicas, sem nunca abandonar (completamente) a herança pretérita de diferentes grupos, classes e indivíduos.

A atividade e o espírito são sociais tanto no conteúdo como na origem; são atividade social e espírito social. O significado humano da natureza só existe para o homem social, porque só neste caso é que a natureza surge como laço com o homem, como existência de si para os outros e dos outros para si, e ainda como componente vital da realidade humana: só aqui se revela como fundamento da própria experiência humana. Só nesse caso é que a existência natural do homem se tornou a sua existência humana e a característica se tornou, para ele, humana. Assim, a sociedade constitui a união perfeita do homem com a natureza, a verdadeira ressurreição da natureza, o naturalismo integral do homem e o humanismo integral da natureza. (Marx [1844] 2003, p. 139-40). 
Assim, hoje pode tudo estar morto, a não ser o Estado e, com isso, a atualidade de Marx, do marxismo e da crítica hegeliana, que continua plena, afirma Henri Lefebvre. A proposta comunista e revolucionária de Marx, levada a cabo por Lenin e Engels, é sintetizada por um esquema no qual, num primeiro plano, haveria: (i) mudança concreta do Estado, depois (ii) construção de outro modelo sob comando do trabalhador e, mais além, (iii) pôr fim ao Estado e à política decadente, convertendo a economia e a política em qualidades do social. Nesta proposta, a classe trabalhadora deveria elevar o Estado ao ponto de sua extinção, dando um salto qualitativo, sem especulações, ao assumir as contradições por uma análise científica e pela concretização do social. De outra forma, a emergência do trabalhador gera, também, uma grande contradição, que é a tomada do poder e sua própria destruição. Simultaneamente, afirma, reestrutura e destrói o Estado; desenvolve o social e a necessidade do Estado desaparece, por decadência.

A ideia de revolução em Marx, Engels, Lenin é total: ascensão do social em detrimento do político e do econômico. Todavia, até mesmo a lógica formal foi convertida em ferramenta de Estado, o que é característico do poder político e tecnocrático. De fato, ao resgatar a essencialidade da proposta de Marx, vê-se que o mundo atual nada tem de marxista, pois hoje o saber institucionalizado/oficializado tornou-se uma monstruosidade, dado pelo controle e direcionamento do saber; a lógica (formal) está presente no ordenamento do modo de produção, no Estado (o qual, vinculado ao administrativo "equilibrado", mimetiza as contradições reais); quem não se vale de uma "logicidade" em seu projeto que visa à coerência rigorosa? As lógicas devem ser avaliadas como estratégias, objetivos, agentes; apesar da atualidade de Marx, a lógica dialética parece vencida, eliminada (Lefebvre, [1976] 2010), especialmente no seio acadêmico, o qual se faz, cada vez mais, promíscuo, quantitativo, superficial e pervertido, do ponto de vista da produção do conhecimento.

No contexto do pensamento de Marx, destituído o Estado, resta ao trabalhador e à sociedade viver em liberdade, utopia necessária e emergência de uma esperança, na fase do capitalismo avançado. Marx não apenas constata, mas projeta, propõe e anuncia o potencial das transformações revolucionárias, nas quais o ser humano pode buscar, em meio a uma consciência complexa e preditiva, o compasso entre crescimento e desenvolvimento, a realização do social e da liberdade, dados por saltos qualitativos.

Entretanto, reafirma-se, o mundo atual não tem nada de marxista. As antigas alienações catalisaram-se e surgiram novas: alienação dos trabalhadores, das mulheres, das crianças, dos colonizados, que se superpõem à alienação política (pelo Estado todo 
poderoso), à alienação tecnológica, à alienação mediante o espaço, assegura Henri Lefebvre. Ao confundir crescimento e desenvolvimento (com a vitória do crescimento), sem separá-los e operacionalizá-los em uma simultaneidade, o mundo atual não indica a estratégia (que seria positiva) da transformação política antes do crescimento; estimula é o obscurecimento quase que completo do desenvolvimento em prol do crescimento e do poder de controle e de dominação socioespacial (no campo e nas cidades). O desafio é, inclusive, direcionar a produção do conhecimento acadêmico a benefícios reais sociais coletivos, de maneira a retirar as ciências humanas (caso da Geografia) das garras do poder político, que força sua razão instrumental, fechada em si por meio do cálculo e de sua tecnificação (favorável à demência epistêmica), via financiamentos específicos em prol do confinamento territorial do capital.

Nessa lógica é que Henri Lefebvre sugere o amadurecimento em relação ao pensamento de Marx, em consonância com Hegel e Nietzsche, em nome de uma estratégia de futuro, para ressurgência de uma possibilidade social-política, pela via prática-revolucionária da classe trabalhadora; o que pode levar ao efetivo caminho de realização da vida e de abandono do "reino das sombras", em nome do vivido e do cotidiano, de fato. A universidade deveria assumir a dianteira dessa transformação, via debate, esclarecimento e prática sociais extensivas.

Na geografia histórica do mundo moderno, com foco na formação espacial de uma sociedade técnica de conflitos perenes (refletida no que se denomina, universalmente, campo e cidade), há o vigor de um Estado que pesa sobre a classe trabalhadora, para organizar a produção e o consumo, vigiar para proteger o melhor percurso do modo de produção (a todo custo e por mecanismos os mais opressores ou punitivos) e garantir a mais valia. Uma nova discussão geográfica crítica deve propor, a partir de Marx e na atualidade, mais que a metamorfose de um Estado enquanto órgão acima da sociedade para órgão decididamente subordinado a ela; deve estimular práxis que conduzam ao esfacelamento real das perversidades espaciais evidentes (no campo e nas cidades), por meio da dialética espacial, ou seja, através do espaço agido, pois é reflexo de todas as estratégias sociais existentes.

Para Marx, a racionalidade nova, superior qualitativamente à racionalidade filosófica, nasceria a partir de um momento da prática social (da indústria e do trabaIho, diz Henri Lefebvre). A classe trabalhadora ou operária se colocaria, de forma revolucionária, como sujeito da ação política, no lugar do próprio Estado, para a transformação real do mundo concreto (e porque não dizer do cotidiano e do vivido enquanto totalidades dinâmicas de uma vida ativa e de existências orgânicas, lógicas, materiais harmônico-desarmônicas e, inclusive, imaginárias). 
A transformação social almejada por Marx fixa no reino das sombras, é obscurecida pela força e o império de um Estado de tipo hegeliano (absoluto, doutrinador, vitorioso); o vivido continua entre parênteses e perambula à sombra deste Estado. Apesar disso, não há entre o espaço-tempo moderno de Marx e o espaço-tempo presente uma ruptura total, uma descontinuidade absoluta. Como diz Braudel (1985), as experiências do passado não param de se prolongar na vida presente, devido a uma espécie de razão de ser da história.

\section{A POESIA, O VIVIDO E O PROGRESSO EM NIETZSCHE}

Lefebvre introduz o Dossiê Nietzsche com o mote de seu pensamento, a caracterizar para o mesmo o mundo moderno: a vontade de poder (poder para dominar). Para Nietzsche, o recurso adotado pelo poder é a linguagem, o que o faz rechaçar toda filosofia sistematizada até então, a qual se fundamentava nas representações dos mitos de origens, do início do mundo, do homem, da consciência e do pensamento (Deus, a Transcendência, a Ideia), na dualidade bem e mal, pensamento e matéria. Percurso no qual, para Nietzsche, a filosofia se perdeu "no vão retorno ao original" e "na contemplação de si mesma" (Lefebvre, [1976] 2010, 188). Filosofia que teria fracassado na busca de um sistema de ensino atinente a representações e a ideologias que conceberiam o saber. Sobre o lugar da linguagem em seu pensamento, o próprio autor considera,

A linguagem como suposta ciência. - A importância da linguagem para o desenvolvimento da cultura está em que nela o homem estabeleceu um mundo próprio ao lado do outro, um lugar que ele considerou firme o bastante para, a partir dele, tirar dos eixos o mundo restante e se tornar seu senhor (...) O criador da linguagem não foi modesto a ponto de crer que dava às coisas apenas denominações, ele imaginou, isto sim, exprimir com as palavras o supremo saber sobre as coisas; de fato, a linguagem é a primeira etapa no esforço da ciência. (Nietzsche, [1878] 2005, p. 20-21).

A interpretação de Nietzsche sobre o mundo ocidental foi implacável, ao considerar o pensamento europeu, sobretudo greco-romano. Nietzsche obscurece o concebido e o percebido para lançar luz sobre o vivido, argumenta Lefebvre. Em nome de um interesse geral, de ordem política, econômica ou religiosa, o sofrimento e a humilhação em que muitos vivem são moralmente justificados, o que legitima a humildade mediante o saber (caso de uma Europa dominada pelos homens de religião, "uma espécie diminuída"). As condições de vida, tanto do que sofre, quanto daquele que detêm o poder são ideologicamente determinadas. Em Nietzsche, a 
história emerge como um caos de azares, vontades e determinismos. ${ }^{8}$ Essa tríade sintetiza sua crítica não ao Estado, como em Marx, mas à ideia e à concepção de uma Civilização "moderna" face à toda "moral cristã-europeia". Em relação ao sofrimento e à humilhação que parecem justificados perante a vida individual, Nietzsche ([1878] 2005, p. 62-63) esclarece,

Enganos do sofredor e do perpetrador. - Quando um homem rico toma um bem ao pobre (por exemplo, um príncipe rouba a amada ao plebeu), produz-se um engano no pobre; ele acha que o outro deve ser um infame, para tomar-lhe o pouco que tem. Mas o outro não percebe tão profundamente o valor de um determinado bem, pois está acostumado a ter muitos; por isso não é capaz de se pôr no lugar do pobre, e de modo algum lhe faz tanta injustiça como ele crê. Cada um tem do outro uma ideia falsa. A injustiça do poderoso, o que mais causa revolta na história, de modo algum é tão grande como parece (...) Não há sinal de maldade em Xerxes (...) quando ele toma a um pai seu filho e o faz esquartejar, porque havia manifestado desconfiança medrosa e agourenta quanto à expedição militar: nesse caso o indivíduo é eliminado como um inseto irritante, ele se encontra baixo demais para que Ihe seja permitido provocar, num conquistador do mundo, sentimentos que o aflijam por muito tempo. Sim, nenhum homem cruel é cruel como acredita o homem maltratado; a ideia da dor não é a mesma coisa que o sofrimento dela. O mesmo se dá com o juiz injusto, ou com o jornalista que engana a opinião pública mediante pequenas desonestidades. Em todos esses casos, causa e efeito estão envoltos em grupos de ideias e sentimentos muito distintos; enquanto inadvertidamente se pressupõe que o perpetrador e o sofredor pensam e sentem do mesmo modo, e conforme esse pressuposto se mede a culpa de um pela dor do outro.

O mundo e o ser humano resultam do azar, ou seja, da combinação de contingências e acasos, menos de um progresso coerente e factual. Frente ao pensamento racional que busca apreender a realidade, ergue-se o vivido que deveria ter primazia para o entendimento do real. Em Nietzsche, a trajetória humana não tem sentido imanente à razão, ao historicismo, à lógica ou à causalidade progressiva; para o filósofo, esse pensamento é superficial, tenta salvar a civilização da sua decadência, nega a conjuntura e o acidente (azar) como fundamentos do surgimento do homem. O próprio evolucionismo exprime isso, o desenvolvimento da vida a partir de acasos, contingências e adaptações, sem qualquer sentido oculto para ser descoberto, afinal o sentido é criado. O progresso, o fortalecimento do homem ou

8 A apologia do azar presta uma nova dimensão à liberdade, ao romper com a servidão da finalidade. "O azar oferece ocasiões, conjuntura favoráveis, organizam nossas necessidades mais pessoais", pois emerge ante a análise como o desejo ou a vontade na vida, não apenas o desejo de dizer 'quero', mas a vontade de poder, poder para dominar. Sobre o terceiro elemento da tríada de Nietzsche, o determinismo, o mesmo enquanto necessidade não é um determinismo exclusivo, mas há múltiplos determinismos que nascem e se esgotam, crescem e desaparecem (Lefebvre, [1974] 2010, p. 31) 
de uma raça não se centra apenas na famosa luta pela sobrevivência. De acordo com Nietzsche ([1878] 2005, p. 143), tem relevo a "união dos espíritos na crença e no sentido comunitário", a enfrentar "lesões parciais da força estável; justamente a natureza mais fraca, sendo a mais delicada e mais livre, torna possível todo progresso", de maneira a incorporar o novo como benefício.

O que move o ser humano na civilização é, explicitamente, a vontade de poder! Dominação pela dominação, sem justificação elaborada como no passado: em nome de Deus e da Fé. Para Nietzsche, Deus está morto e a civilização moderna europeia, em suas guerras repetitivas, não possui nenhuma justificativa, a não ser a vontade de dominar. Todas as camadas sociais, todos os seres humanos autodenominados "civilizados" expressam esta vontade de poder - por isso, condenar a classe burguesa em favor do proletariado, como faz Marx, pretensa justiça proletária, não seria realizar um projeto melhor, já que a questão central, para Nietzsche, não é a condenação de um grupo, mas da civilização como um todo, como indica a passagem seguinte,

Palavras de má reputação. - Fora com as palavras 'otimismo' e 'pessimismo', utilizadas até a saciedade! Pois cada vez mais faltam motivos para empregá-las: apenas os tagarelas ainda têm inevitável necessidade delas. Pois por que desejaria alguém no mundo ser otimista, se não tiver que defender um deus que deve ter criado o melhor dos mundos, caso ele mesmo seja o bem e a perfeição - mas que ser pensante ainda necessita da hipótese de um deus? - No entanto, falta igualmente qualquer motivo para uma profissão de fé pessimista, se não houver interesse em irritar os advogados de Deus, os teólogos ou os filósofos teologizantes, afirmando vigorosamente o contrário: que o mal governa, que o desprazer é maior que o prazer, que o mundo é uma obra malfeita, a manifestação de uma perversa vontade de vida. Mas quem se importa ainda com os teólogos - excetuando os teólogos? - Deixando de lado a teologia e o combate que se faz a ela, fica evidente que o mundo não é nem bom nem mau, e tampouco o melhor ou o pior, e os conceitos 'bom' e 'mau' só têm sentido em relação aos homens, e mesmo aí talvez não se justifiquem, do modo como são habitualmente empregados: em todo caso, devemos nos livrar tanto da concepção do mundo que o invectiva como daquela que o glorifica (...) O cristianismo nasceu para aliviar o coração; mas agora deve primeiro oprimi-lo, para mais tarde poder aliviá-lo. Em consequência, perecerá. (Nietzsche [1878] 2005, p. 35)

A pretensa explicação da civilização, através do sistema dialético concebido por Hegel, sustentado pela História, pela Linguagem e pelo Saber, é diretamente atacada por Nietzsche, que entende que o conflito dialético não é concebido, mas vivido. Se Nietzsche enfatiza uma história e uma analogia entre antiguidade greco-romana e Europa do final do século XIX, é para buscar filiações, reconstituir genealogias da Teoria da História, da Linguagem e do Saber, que o autorizam a realizar críticas a Sócrates (o 
homem que sabe muito e vive pouco), tendo como alvo Hegel e a modernidade.

Nietzsche condena a ciência e a filosofia em sua missão civilizatória - nas tentativas de descobrir o sentido da realidade - porque a civilização, em seus resquícios, não estaria neste sistema racional, mas na emergência do vivido justamente nos países que, sendo mais pobres, conservam no viver coisas da civilização já perdida. Argumenta o filós ofo que congregam-se tantos poetas e artista sobre os países atrasados não porque sejam "atrasados", mas porque mantém um pouco da civilização que perdem os países "modernizados"; as relações sociais, apesar da pobreza, são neles mais "ricas". Sobre os desígnios da arte, o autor defende que:

A nossa última gratidão para com a arte. - Caso não tivéssemos aprovado as artes e não tivéssemos inventado esta espécie de culto do não-verdadeiro, não poderíamos suportar ver o que nos mostra agora a Ciência: a universalidade do não-verdadeiro, da mentira, da loucura e do erro como condições do mundo intelectual e sensível. A integridade teria, por consequência, a náusea e o suicídio. Mas, à nossa integridade, opõe-se uma contrapartida que ajuda a evitar semelhantes consequências: a arte, enquanto encarada como boa vontade da ilusão (...) Enquanto fenômeno estético, a existência ainda nos é suportável e a arte nos dá os olhos, as mãos, sobretudo a boa consciência, que é necessária para poder fazer de nós mesmos este fenômeno. É preciso que, de vez em quando, descansemos de nós próprios, olhando-nos de cima e de longe e, com o longínquo da arte, rir ou chorar de nós e por nós mesmos: é preciso descobrimos o herói e também o louco que se dissimulam na nossa paixão do conhecimento; sejamos felizes, de vez em quando, com a nossa estupidez, para que possamos continuar felizes com a nossa sabedoria! (...) Como poderíamos nos privar da arte e do louco? (Nietzsche [1882] 2004, p. 103-104)

Os determinismos - histórico, biológico, filosófico (e geográfico) - são expressões da "doença do ser", fruto do pensamento racionalizado, no qual há um acúmulo evolucionário de conhecimento que cria padrões históricos coerentes para balizar, pretensamente, ações mais consistentes. Criam-se padrões históricos, padrões explicativos, sistemas - que buscam determinar a vida como um todo. Essa crítica nietzschiana favorece o questionamento de uma geografia petrificada na racionalização abstrata dos dados e das estatísticas, para a qual o real se dá unilateralmente, por meio de cabrestos e de fórceps lógico-formais superficializadores.

Uma vez que estes determinismos, supostamente, dão as explicações para toda condição de existência, para Nietzsche, a possibilidade de mudança no vivido só se estabelece quando o indivíduo concentra sua atenção em seu estado de humilhação e sofrimento, ao invés de interiorizar tais explicações tidas como concepção generalizada do saber. Nietzsche inverte o sentido da perspectiva de Hegel, para quem 
a perfeição é alcançada via Estado. A subjetividade concreta do vivido também não está na perspectiva de Marx, cuja teoria encara-a como a ideologia. Nietzsche não separa o vivido do subjetivo. A história da Antiguidade, do Medievo e do Renascimento ainda podem ser sentidas no corpo e no pensamento pelo indivíduo como resultado dos paradigmas socialmente construídos, antes mesmo do que qualquer forma de concepção científica e filosoficamente autorizada. Entretanto, esta condição é de alguma forma anestesiada quando a consciência se volta apenas para a própria existência, como deixa claro o trecho seguinte,

A grande maioria dos homens suporta a vida sem muito resmungar, e acredita então no valor da existência, mas precisamente porque cada um quer e afirma somente a si mesmo, e não sai de si mesmo como aquelas exceções: tudo extrapessoal, para eles, ou não é perceptivo ou o é, no máximo, como uma frágil sombra. Portanto, para o homem comum, cotidiano, o valor da vida baseia-se apenas no fato de ele se tomar por mais importante que o mundo. A grande falta de imaginação de que sofre faz com que não possa colocar-se na pele de outros seres, e em virtude disso participa o menos possível de seus destinos e dissabores. Mas quem pudesse realmente deles participar, teria que desesperar do valor da vida; se conseguisse apreender e sentir a consciência total da humanidade, sucumbiria, amaldiçoando a existência, - pois no conjunto a humanidade não tem objetivo nenhum, e por isso, considerando todo o seu percurso, o homem não pode nela encontrar consolo e apoio, mas sim desespero. Se ele vê, em tudo o que faz, a falta de objetivo último dos homens, seu próprio agir assume a seus olhos caráter de desperdício. Mas sentir-se desperdiçado enquanto humanidade (e não apenas enquanto indivíduo), tal como vemos um broto desperdiçado pela natureza, é um sentimento acima de todos os sentimentos. - Mas quem é capaz dele? Claro que apenas um poeta: e os poetas sempre sabem se consolar (Nietzsche [1878] 2005, p. 38-39).

Nesse sentido, a dor pode se tornar alegria, por meio da poesia, da música, da dança e do teatro; metamorfoseia-se a realidade decadente através da arte. Em Nietzsche, "o sofrimento tem tanto sentido como a alegria e o gozo. A noite tem tanto sentido e mais profundidade que o dia, a morte mais que a vida. Coisa que os poetas compreenderam melhor que os filósofos e mais ainda que os teólogos" (Lefebvre [1976] 2010, p. 289).

Dessa forma, Nietzsche se torna "poeta", dominando o saber pela poesia. Ele não nega a razão, mas refuta a prioridade de uma representação do real em nome do saber, em detrimento do vivido, do não-saber. Embora se sirva da própria ciência, prioriza a poesia como meio do conhecer. Segundo ele, não há uma necessidade única, um projeto único, um determinismo exclusivo, mas as trajetórias sociais são múltiplas e distintas, de forma que são os povos que atribuem os sentidos e os valores das coisas, e não o saber, aclamado pela política ou pela religião. Segundo Lefebvre, isso explica 
porque Nietzsche enfatizou a civilização acima da sociedade (como o fez Marx) e do Estado (como o fez Hegel). Na concepção de civilização, considera-se o indivíduo no confronto às pressões estatais, sociais e morais. As forças políticas afirmam-se sobre o vivido, mas os indivíduos podem protestar utilizando a arte como recurso. Sua recusa a um projeto único, aos determinismos advindos da política e da religião, especialmente sua recusa às "ideias modernas", são identificados na seguinte passagem,

Raras dores há como as sentidas quando, uma vez, se viu, se adivinhou, se sentiu como um homem extraordinário se desviou do seu caminho e degenerou. Principalmente aquele que tem a rara capacidade de saber discernir o perigo global da degenerescência do 'próprio homem', aquele que, como nós, reconheceu a monstruosa casualidade que até agora desempenhou o seu papel quanto ao futuro do homem - papel esse em que não interveio nem uma mão, nem mesmo um dedo de 'Deus'! Aquele que adivinha a fatalidade oculta na estúpida inocência e credulidade das 'ideias modernas' e, mais ainda, em toda a 'moral cristã-européia' (...) A degenerescência global do homem até àquilo que é considerado pelos cretinos e boçais socialistas como o seu 'homem do futuro' - seu ideal! - essa degenerescência e amesquinhamento do homem até ao perfeito animal de rebanho - ou, como eles diriam, até ao homem da 'sociedade livre' -, essa bestialização do homem até converter-se em animúnculo dos direitos iguais e reivindicações igualitárias é possível não haja dúvida! Qualquer um que tiver refletido nesta possibilidade até às suas últimas consequências sente uma náusea que os outros homens desconhecem - e talvez pressinta também uma nova tarefa! (Nietzsche [1886] 2002, p. 118-119).

Lefebvre ainda apresenta ideias que são centrais na análise de Nietzsche sobre a modernidade e que reforçam sua perspectiva filosófica: o ressentimento, a repetição, a mimeses, o reflexo, o retorno e recurso ao corpo, a infinitude.

Para Nietzsche, o ressentimento é produto da humilhação. A alienação daqueles que se submetem à vontade de poder de outros nega este estado de humilhação. Assim, o "oprimido e o escravizado engendram em si mesmos valores que lhes permitem viver [...] aceitando as condições de sua existência"; para ele, a única forma de cura desse ressentimento é "superar a natureza, ou seja, a vontade de poder" (Lefebvre [1976] 2010, p. 241, 243).

A repetição é fundamental no mundo moderno, ela se massificou por meio das técnicas e das forças produtivas até o ponto de engendrar ideologias ocultas. Nietzsche põe em primeiro plano o repetitivo a partir da arte, situando-se na fronteira do concebido e do vivido (saber e não-saber). O vivido (não-saber) é "o gozo e o sofrimento, sempre repetidos, sempre novos" (Lefebvre [1976] 2010, p. 245). Já o concebido, ao qual dirige sua crítica, é o saber que, por sua repetição (memória, operações reiteradas, lógica etc.), é meramente o saber do repetitivo. 
A mímeses aparece como identificação direta com um modelo: os submetidos, os escravizados, os oprimidos, as pessoas dominadas pelo ressentimento se identificam com o homem forte, vencedor, titular e amo. Ela ainda procede, indiretamente, de uma imagem ou símbolo, emitidos ou não pelo poder superior (advindo da religião e da política). Em ambos os casos, a mimeses assegura a repetição do saber, produzindo simulacros mediante os quais os indivíduos se inserem em uma realidade sociopolítica repleta de ideologias e discursos. Isso é o que sustenta a estrutura sociopolítica e reproduz o topo da sociedade pela base.

Para Nietzsche, além desse "reino da identidade, das máscaras e marcas, mais além da mímeses, mais além do reino das sombras, se abre o horizonte solar" (Lefebvre [1976] 2010p. 258). O reflexo (ato de refletir da consciência) é fundamental para a transformação do real, bem como o que ele trata de retorno e recurso ao corpo (pelo gozo na poesia e nas artes), uma vez que todo o peso, pressão e coação da tradição na sociedade se abate sobre ele, fragmentando-o. 0 corpo não se recupera de sua fragmentação por meio de um status teórico ou clínico, por isso não basta o repúdio marxista da divisão do trabalho ou uma interpretação psicanalítica à luz do simbólico e do imaginário. É preciso conceber o corpo nos seus variados níveis, como uma totalidade: o empírico (corpo-objeto), o sociopolítico (corpo-sujeito), o poético (a unidade do corpo). Os poetas e a poesia, ainda, são apontados como meios de aliviar a vida, mesmo que provisoriamente,

Os poetas tornando a vida mais leve. - Na medida em que também querem aliviar a vida dos homens, os poetas desviam o olhar do árduo presente ou, com uma luz que fazem irradiar do passado, proporcionam novas cores ao presente. Para poderem fazer isso, eles próprios devem ser, em alguns aspectos, seres voltados para trás: de modo que possamos usá-los como pontes para tempos e representações longínquas, para religiões e culturas agonizantes ou extintas. Na realidade, são sempre e necessariamente epígonos. Certamente há coisas desfavoráveis a dizer sobre os seus meios de aliviar a vida: eles acalmam e curam apenas provisoriamente, apenas no instante; e até mesmo impedem que os homens trabalhem por uma real melhoria de suas condições, ao suprimir e purgar paliativamente a paixão dos insatisfeitos, dos que impelem à ação (Nietzsche [1878] 2005, p. 108).

Assim, no viés nietzschiano, somos infinitos não pela consciência, saber ou pensamento, mas pelo corpo no mundo. $O$ espaço e o tempo são infinitos, porém são discernidos ao reencontrar-se com o "aqui-agora" do corpo de cada um de nós. "Cada lugar e cada instante remetem à totalidade do espaço e do tempo" (Lefebvre, [1974] 2010, p. 271). Por emergir dessa relação espaço-temporal, envolvido nos azares, o corpo está no centro da análise de Nietzsche. Sua crítica ao poder proclama a gênese de relações novas: entre o corpo e a consciência, entre o concebido e 
o vivido, entre o saber e o não-saber.

O dossiê Nietzsche, apresentado por Henri Lefebvre, indica sua condenação à ciência e à filosofia que negligenciavam, em fins do século XIX, questões brutais, origens e duras condições sociais impostas pelo capitalismo, via acumulação de capital. Fala pouco do capitalismo e da burguesia, para evitar erros e, sobretudo, por desprezá-los e condená-los amplamente, sem pensar que haja neles um objeto digno de interesse; também porque os engloba no judeocristianismo, lembra Henri Lefebvre. Também, deve-se enaltecer que, para Nietzsche, "a poesia não impede o conhecer". Ao partir do vivido, penetra no conhecer diferente qualitativamente do saber, pois considera que é nele que se reproduzem relações de força, de poder e os sentidos recriados no cotidiano. Rechaça, veementemente, o saber como tal, pois é separado (da vida cotidiana, do povo), erigido (em instituições - como a Universidade e a Igreja) e fundido (em produção econômica e atividades políticas) para se fazer propriedade do capital e seu poder hegemônico. Por isso, Henri Lefebvre sintetiza com a afirmação de que, para Nietzsche, todos os valores e sentidos estão mortos. Hoje, o valor como sentido só pode vir do vivido, para transfigurá-lo em novo viver.

A geografia histórica do mundo moderno, no cerne da concepção nietzschiana de civilização e seus valores, reflete um progresso sem coesão e sem coerência, dominado por e dominante do caótico e da fragilidade humana, tudo expresso em territórios. E se o conhecimento (objeto do cientista e do filósofo) está associado ao prazer (porque com ele se tem dimensão da força individual ou de grupo) e a dimensões de poder, este mundo irônico de valores morais recicláveis torna-se objeto para inquirições permanentes e sempre renovadas. A crítica nietzschiana à civilização moderna formatada por um "cristianismo político" abre caminho ao pensamento do que os "grandes" homens (nefastos europeus) encobriram: as "pequenas" coisas que são vigorosos problemas políticos (a nutrição, o lugar, os devaneios vividos no cotidiano, a saúde corporal e mental, o conhecimento novo e de novidades etc.).

\section{CONSIDERAÇÕES FINAIS}

Este ensaio defende a noção de uma geografia do mundo de existências, que se perpetua em choques e contradições sociais, onde o novo e a novidade (no viés das técnicas e das ideias) nunca abandonam (completamente) o passado, ou seja, não há ruptura completa com a história, sempre renovada pelo espaço enquanto reflexo da interação permanente sociedade-natureza. O mundo moderno em Hegel, Marx e Nietzsche, longe de indicar distinções absolutas deste mesmo mundo, é um encaminhamento reflexivo de convergências ou aproximações entre o material (vulgar e não vul- 
gar), o ideal (metafísico e não metafísico) e o existencial (epistemológico e ontológico).

À Geografia ou às geografias não Ihes cabe escolha. O mundo moderno se constitui do entrelaçamento concreto da matéria, da ideia e das existências; o diferencial reside na seleção individual do cientista ou do filósofo sobre o ponto ou os pontos de vista a se adotar, ou seja, sua priorização de método. Hegel (em prol do Estado), Marx (por outra Sociedade) e Nietzsche (pela crítica moral à Civilização), à luz de Henri Lefebvre e da inquirição geográfica estabelecida, apresentam ângulos de visada particulares sobre um mesmo objeto: o mundo moderno de mutações contínuas, mas que se refaz sempre em nome da esperança do "progresso".

Como rechaçar, geográfica e historicamente, que o "Estado se serve do saber para utilizar a força bruta" (Hegel), que "uma racionalidade nova, superior à racionalidade filosófica, pode nascer de um momento da prática social: da indústria e do trabalho" (Marx), ou que "o sofrimento tem tanto sentido quanto a alegria e o gozo, no bojo de valores que os poetas compreenderam melhor que os filósofos e mais ainda que os teólogos" (Nietzsche)? A unidade presente nos autores elencados está na potência e na fragilidade do elemento triádico que sustenta o mundo moderno: o saber-poder-consciência, de maneira que cada um desses termos adquire um sentido específico na avaliação dos autores, como avaliado.

Henri Lefebvre favorece a compreensão de que a tríade hegeliana funda-se em necessidades, trabalho e saber (pelo Estado), a tríade marxiana estrutura-se em exploração, opressão e humilhação (pela Sociedade), a tríade nietzschiana pauta-se em moral, vontade de poder e arte fundamento da sociedade (pela Civilização). No fundo, os autores propõem um novo conhecimento da modernidade, de maneira que "o conhecer revela a crueldade do vivido, as implicáveis relações de força que o fazem como é" (Lefebvre [1976] 2010, p. 228).

A geografia histórica do mundo moderno constitui-se de uma produção objetiva, que é socioeconômica (categorizada por Marx), sem deixar de ser subjetiva, no sentido poético-artístico síntese do social (debatida por Nietzsche). Os territórios conquistados, dominados e complexizados esboçam, distintamente, que as diferenças se dão pelos sentidos atribuídos pela sociedade, historicamente, ao objetivo, ao subjetivo e ao ideal: a existência se faz daí (e Hegel, Marx e Nietzsche apresentam suas propostas para esse entendimento). Ante as contradições e conflitos reinantes, territórios comportam lugares que podem ser decifrados pelas suas objetividades e subjetividades, que se perfazem reciprocamente.

Por fim, o mundo moderno está sempre se refazendo e é revelado pelo território e seus sentidos concebidos, percebidos e vividos. Múltiplos são os caminhos para uma interpre- 
tação reveladora deste mundo que não cessa, sendo factível quer seja pela concreticidade de práticas radicais revolucionárias entendidas no bojo da História (Marx), quer seja pela subjetividade inerente ao corpo que guarda o humano demasiado humano a desmantelar a ideia e a prática de Civilização (Nietzsche) ou ainda pela vitória de um edifício estatal que a tudo e a todos controla (Hegel). A Geografia, enquanto campo do saber voltado ao espaço geográfico, não deve se eximir desse debate que, em essência traz, por meio da filosofia, elementos para a construção de seu edifício epistemológico e de método.

\section{REFERÊNCIAS BIBLIOGRÁFICAS}

BRAUDEL, F. (1985) La dynamique du capitalisme. Paris: Les Editions Arthaud.

DUSSEL, E. (2000) Europa, modernidad y eurocentrismo In: LANDER, E. (org.). La colonialidad del saber: eurocentrismo y ciências sociales. Perspectivas latinoamericanas. Buenos Aires: CLACSO.

FOUREZ, G. (1995) A construção das ciências: introdução à filosofia e à ética das ciências. São Paulo: EdUNESP.

HEGEL, G. W. F. (1997) Princípios de filosofia do direito. Trad. Orlando Vitorino. São Paulo: Martins Fontes.

LANDER, E. (2000) Ciencias sociales: saberes coloniales y eurocentricos. In: LANDER, E. (org.). La colonialidad del saber: eurocentrismo y ciências sociales. Perspectivas latinoamericanas. Buenos Aires: CLACSO.

LEFEBVRE, H. (2010) Hegel, Marx, Nietzsche o el reino de las sombras. 12a Ed. Trad. Mauro Armiño. Madrid: Siglo XXI Editores.

MARX, K. (2003) Manuscritos Econômicos Filosóficos. Trad. Alex Marins. São Paulo: Martin Claret.

MARX, K.; ENGELS, F. (2003) Manifesto do Partido Comunista. Trad. Pietro Nassetti. São Paulo: Martin Claret.

NIETZSCHE, F. (2005) Humano, demasiado humano. Trad. Paulo Cesar de Souza. São Paulo: Companhia das Letras.

NIETZSCHE, F. (2004) A Gaia Ciência. Trad. Jean Melville. São Paulo: Martin Claret.

NIETZSCHE, F. (2002) Para além do bem e do mal: prelúdio a uma filosofia do futuro. Trad. Alex Marins. São Paulo: Martin Claret.

SOJA, E. (1993) Geografias Pós-Modernas. Rio de Janeiro: Ed. Jorge Zahar. 